\title{
MODERNIZING BANKING REGULATION
}

\author{
CLIFToN H. KREPS, JR.*
}

\section{INTRODUCTION}

The nation's I4,000 commercial banks are unique; they are privately owned profitseeking businesses which also supply us with most of the stuff-demand depositsthat we use for money. They also serve other important public purposes: They constitute the national payments mechanism, which makes it convenient to use demand deposits as money; they serve as pools of community liquidity, by holding demand and time deposits; and finally, they are the largest single source of credit accommodation in the economy, by virtue of their ability to create money.

It is the relationship of commercial banks to the nation's monetary system that provides the traditional rationale for banking regulation, which aims at safeguarding the banking system in its national economic role of principal money supplier. To the extent that this purpose is achieved, either by banking regulation or otherwise, banks as the payments mechanism and as pools of community liquidity will also be protected. They will not fail, and depositors will not suffer losses.

A newer and nontraditional purpose-preserving banking competition-is now also assigned to banking regulation, but this function has emerged only within the last decade. It aims to protect not the depositing but the borrowing segment of the economic community, preventing the monopolistic exploitation of borrowers by assuring them of the existence of an adequate number of alternative sources of credit accommodation. Both the propriety of this objective and the proper means of achieving it are the subject of a current, hotly contested dispute known as "the banking competition controversy."

We shall first concern ourselves with traditional banking regulation. In this respect, the first section of this paper argues that banks are not only unique in their national economic role of money suppliers; they are also unique in the sense that, today, the heavy overlay of public regulation to which they are subject because they create money is obsolete. The second section then suggests how traditional regulation might be modernized, or streamlined. In the third section, the new regulatory goal of preserving banking competition is examined, and the future of banking regulation is briefly evaluated.

* A.B. I94I, College of William and Mary; M.A. 1942, University of North Carolina; Ph.D. I948, Duke University. Wachovia Professor of Banking, Graduate School of Business Administration, University of North Carolina. Formerly economist for the Federal Reserve Bank of New York. Author, Money, Banking and Monetary Policy (ig62); Character and Competitiveness of Locar Banking (1964); and various other works on banking topics; co-author [with David T. Lapkin], IMProvino THB Competition for Funds Between Commercial Banks and Thrift Instirutions (1963). Contributor to economic and financial periodicals and consultant to private financial institutions and public financial agencies. 


\section{The Obsolescence of Traditionai Banking Regulation}

The public regulation of commercial banking includes controlling entry into the banking business by placing restrictions on new bank chartering and imposing statutory limitations on existing bank management's freedom to act in certain strategic areas of individual bank operations: market expansion through branching; ${ }^{1}$ the acquisition of funds (deposits); and both the acquisition and composition of earning assets (loans and investments).

In the United States, banking regulation has a history as old as that of banking. Until very recently, the purpose has always been the same-contributing to the maintenance of public confidence in the circulating medium of exchange, much of which banks have always supplied and most of which they now supply. The particular contribution of banking regulation to the maintenance of public confidence in the circulating medium of exchange consists of attempts to maintain public confidence in the banks which supply it by maintaining sound individual bank operating conditions.

However, it is impossible to maintain public confidence in banks (i.e., to prevent bank failures) only by publicly regulating individual bank operations in the interest of "soundness." Maintaining the banking system in a continuous and effective state of being as a source of money supply requires something else in addition. As we have learned over the years, the soundness of banks both individually and as a system depends much more on conditions prevailing in the economic environment in which banks exist and operate than it does on any degree of publicly imposed regulation of their internal operations. A brief summary of the history of our efforts to maintain confidence in the domestic monetary system via the route of maintaining confidence in the banking system may serve to make this point clearer.

\section{A. The National Bank Acts and the Death Tax on State Bank Notes}

As legislative measures of banking regulation, the National Bank Acts of $1863^{2}$ and $1864,{ }^{3}$ and the related ten per cent "death tax" imposed by Congress in 1865 on the note issues of state-chartered banks, ${ }^{4}$ were intended to provide a sound and uniform national currency by (I) eliminating state-chartered banking (and thus the issuance of state-bank notes), and (2) providing for a single system of federally chartered national banks to issue new national bank notes.

The National Bank Acts provided for the federal chartering of national banks and for their issuance of national bank notes. Since no bank was then able to earn

\footnotetext{
${ }^{1}$ Here we refer primarily to branching de novo. Branching through merger, and the branching substitute of grouping through the use of holding companies, are of concern to banking regulation in connection with its new role of preserver of banking competition.

${ }^{3}$ Act of Feb. 25, 1863, ch. 58, 12 Stat. 665, repealed by Act of June 3, x864, ch. 106, § 62, 13 Stat. II8.

${ }^{3}$ Act of June 3, I864, ch. I06, I3 Stat. 99 (codified in scattered sections of I2, I8, I9, 28, 3 I U.S.C.).

'Act of March 3, 1865, ch. 78, $\$ 6,13$ Stat. 484 .
} 
as much as ten per cent on the loans it made by putting its notes into circulation, the tax on state-bank notes was clearly intended to eliminate state-chartered banking. It almost succeeded. But the public acceptability of demand deposits as money, which had been growing steadily over the years, especially in the nation's developing urban centers, had by the last quarter of the nineteenth century developed to the point where the state banks were able to avoid extinction by turning to the process of lending through deposit creation rather than through note issuance. Our present "dual" (federal and state) system of bank chartering and regulation was the result. We will have occasion below to comment on this dual system and the desirability of its perpetuation in this modern age. It was never meant to develop in the first place, and it is perhaps time for it to give way.

\section{B. The Federal Reserve Act of Igr3}

Passage of the National Bank Acts led almost immediately to the discovery that banking regulation could not alone maintain the banking system in a continuous and effective state of being as national money supplier. Something had to be added to protect the banking system from its economic environment. Specifically, the National Bank Acts did not provide the new national banking system with an adequate mechanism for adjusting itself to seasonal changes in the demand for money and credit. Recurring "money panics" (seasonal banking-system liquidity freezeups) thus occurred on the average of about one a decade from the end of the Civil War until passage of the Federal Reserve Act of $1913^{5}$

The Federal Reserve System was specifically designed to prevent such money panics by providing seasonal lender-of-last-resort facilities to the banking system. But it also had a larger purpose as well. It aimed to prevent inflation by combining the received economic doctrine of the time-that supply creates its own demand with the received banking doctrine of the time-that banks should make only productive (that is, short-term, self-liquidating) loans. ${ }^{7}$ By what can only be described as a remarkable historical coincidence, these two theories meshed perfectly. The Federal Reserve's lender-of-last-resort facilities would prevent money panics, and its enforcement of the productive credit theory of lending on the banking system would prevent inflation, which could only result from the extension of unproductive credit. Full employment without inflation was therefore assured. So said we all until r929.

The Federal Reserve Act's effort to promote national economic stability failed, of

${ }^{8}$ Act of Dec. 23, I9r3, ch. 6, 38 Stat. 25 I (codified in scattered sections of 12, 18, I9, 3I U.S.C.).

- This doctrine had no cyclical or secular (growth) dimensions. Thus, the only aggregative economic problems it recognized and thought needed solving were those of ( 1 ) preventing money panics and (2) preventing inflation.

'The productive-credit theory of bank lending gained currency from the fact that until a sizable short-term federal debt and money market mechanism for trading in it came into being in this country in the I930s, banks had no way of supplementing their fractional cash liquidity reserves except through the runoff of their loan portfolios. Loan portfolios therefore needed to be kept as liquid as possible, and productive (i.e., temporary working capital) loans were the most liquid loans of all. 
course, because its primitive theoretical base was utterly erroneous. The banking system's complete cyclical collapse, starting in I929, and the ensuing I929-I932 depression, were both proof positive of the gross nature of this theoretical error.

\section{The Broadening and Deepening of Banking Regulation}

Before the actual nature and extent of the theoretical error were discovered, however, and in the belief that something should be done to shield the banking system from a recurrence of cyclical collapse, the scope and depth of traditional banking regulation were both very greatly enlarged, and the regulatory concept itself was given its current focus and methodology.

Initial study of the weaknesses which had precipitated the collapse of the banking system appeared to suggest that one of the problems was an excessively competitive banking situation. A much broader and thicker layer of banking regulation was therefore devised and superimposed on the banking system to maintain sound future banking conditions by preventing excessive banking competition. This involved:

(I) drastic restrictions on the right of entry into the banking business, by making the acquisition of new bank charters exceedingly difficult; ${ }^{8}$

(2) high barriers to de novo branching;

(3) severe curbs on bank competition for earning assets, through the use of statutory and supervisory prohibitions and restraints on both the volume and the composition of earning assets that banks might legally hold; and

(4) sharp limits on banks' ability to compete for funds, by a prohibition of interest payments on demand deposits and the imposition of administratively variable ceilings on interest payments on time and savings deposits.

Also before the nature and extent of the theoretical error were known, but again in an effort to protect the banking system from its environment, now known to include cyclical influences, two additional types of banking system improvement were legislated. The first enlarged the powers of the central bank to permit it to cope with cyclical as well as seasonal liquidity crises; the second provided for federal insurance of commercial bank deposits.

\section{Enlarging the Powers of the Central Bank}

The central bank's traditional discounting powers were broadened by permitting it to lend additional reserves to the banking system temporarily not only on the security of "real bills"-promissory notes evidencing the previous extension of pro-

\footnotetext{
${ }^{8}$ This curbing of entry occurred only at the federal level originally, and applied only to national banks. It was quickly followed, however, by similarly restrictive legislation at the state level of the dual system of bank chartering. The remaining techniques adopted to prevent excessive banking competition were initially applied at the federal level also; again, state-level action soon followed with respect to the second and third.
} 
ductive credit by the borrowing banks-but also on the basis of government-security collateral and, in any period of serious liquidity emergency, on the basis of any lending arrangements secured to the satisfaction of the Federal Reserve Bank. Much more important, in addition to equipping it to play more fully its traditional but essentially negative role of lender of last resort to the banking system, it was also empowered to affect, influence, and adjust the reserve (liquidity) base of the banking system both positively and continuously, through administrative variation of member-bank reserve requirements and through engaging in open-market operations in government securities. These latter two powers, and the last especially, provided the base of instrumentation on which modern monetary policy could be and subsequently was erected.

\section{E. Providing for Federal Insurance of Bank Deposits}

By providing for federal insurance of bank deposits, Congress acted to break the connecting link between lack of soundness of individual bank conditions and any resultant lack of public confidence in banks and in the continued "moneyness" of bank money. With deposit insurance in effect, depositors cannot lose, or could not if they all were fully insured, no matter what the state of banking conditions may be. As far as it goes, deposit insurance has been very successful. However, the insurance covers deposits in only 13,876 of the nation's 14,324 banks, and limits on the amount of insurance per account further restricts its coverage. When accounts were insured only up to $\$$ I0,000, only about fifty-five per cent of the nation's bank deposits were covered; the recent increase of the maximum insured amount from $\$$ ro,000 to $\$ 15,000^{\circ}$ has raised this percentage to about fifty-eight per cent, ${ }^{10}$ a virtually minuscule increase in risk. ${ }^{11}$

The uninsured depositors are the larger and more sophisticated ones, moreover, with balances in excess of $\$ 15,000$, and the uninsured banks are the nation's smallest banks. Analysis of the liquidity crisis of the early I930s suggests that it was the larger and more knowing depositors who precipitated the massive and disastrous runs on the banks that then occurred. Analysis of the current banking situation suggests that large banks almost never fail any more; only small banks do. For both these reasons, the extension of deposit insurance to cover all bank accounts in all banks would seem a desirable adjunct to streamlining banking regulation.

Extension of the deposit insurance program from the present $\$ 15,000$ limitation to full coverage of accounts in presently insured banks would increase insured deposits

\footnotetext{
${ }^{8}$ Financial Institutions Supervisory Act of 1966 , $\$ 301(c)$, 12 U.S.C.A. $\$ 1821$ (a) (Supp. 1966).

${ }^{10}$ These estimates are derived from a survey of insured accounts and deposits in insured banks according to the size of account on November I8, 1964. I964 FDIC ANN. REp. 88 (table 20).

${ }^{11}$ See Financial Institutions Supervisory Act of 1966, Conference Report, H.R. Rep. No. 2232, 8gth Cong., $2 \mathrm{~d}$ Sess. 4 ( 1966$)$ : "It is the understanding of the conferees that the adequacy of this increase should be given further congressional attention within a reasonable time." It is to be hoped that further legislation will soon bear out this understanding.
} 
by approximately $\$ 43$ billion, roughly a seventy-three per cent increase in risk. ${ }^{12}$ Addition of the deposits of presently uninsured banks would increase insured deposits by only $\$ 2$ billion more. The total possible increase of $\$ 145$ billion in insured deposits involves only a negligible increase in the real risk exposure of our deposit insurance underwriter, the Federal Deposit Insurance Corporation, however. This minute increase in risk results from the fact that, as noted, large banks almost never fail any more; and the additional fact that very few small banks fail any more, either-the average has been only three a year since 1942. In addition, the FDIC has developed the ability to hold its losses to a minimum even where failure occurs, by having the failed bank taken over by a receiver or a competitor. ${ }^{13}$

\section{F. Underwriting National Prosperity Insurance}

Now we return to the subject of the gross theoretical error-reflected in predepression beliefs that supply creates its own demand and that the extension of productive credit is never inflationary. According to these beliefs, the depression simply could not have occurred. The fact that it did forced a thorough re-examination and led to a complete reconstruction of economic and monetary theory.

From this reconstruction the conclusion emerged that it is not supply that creates its own demand but demand (aggregate expenditure) that creates its own supply, at least up to full employment levels of output. Thereafter, if aggregate expenditure continues to increase, inflation results. As thus reformulated, modern economic and monetary theory suggests that continued maintenance of sound economic conditions-a high, cyclically stable, and secularly expanding level of economic activity, accompanied by relative price stability-may be achieved by controlling the economy's rate of aggregate money spending for output. Time and further thought have provided the tools for doing this: modern monetary policy, built on the enlarged base of central bank powers mentioned above and dedicated to controlling the rate of change in the money supply; and functional (or compensatory) federal fiscal policy, which (I) helps monetary policy prevent lapses from full employment by compensating for deficiencies in aggregate private spending through incurring public bud-

\footnotetext{
${ }^{12} \mathrm{By}$ way of comparison, increasing deposit insurance coverage from the present $\$ 15,000$ maximum to $\$ 25,000$ would increase insured deposits by but $\$ 2 \mathrm{r}$ billion, or $11 \%$. Even raising the insured maximum from $\$ I 5,000$ to $\$ 100,000$ would increase insured deposits by only $\$ 59$ billion, or $30 \%$, while leaving about $\$ 85$ billion-roughly a quarter-of total deposits in insured banks still uninsured. See note ro stcpra.

${ }^{13}$ On October 12, x966, the Public Bank of Detroit, which had assets of \$132 million on December 3I, 1965, "was declared insolvent, placed in receivership, and sold to the Bank of the Commonwealth" in what was believed to be the largest bank failure since 1933. Wall Street Journal, Oct. 13, I966, at 2, col. 2. The FDIC put up $\$$ Io million in a guaranty fund to provide for losses to the Bank of the Commonwealth resulting from defaults of the Public Bank's loans. As a result of the merger, all the depositors of the Public Bank, including those with deposits in excess of the $\$ 10,000$ insurance limit, were assured their money, but it seemed doubtful whether the Public Bank's shareholders would recover anything on their investments. (It appeared at that time, however, that the FDIC's loss would be no more than the $\$$ ro million in the guaranty fund and possibly even less.)
} 
getary deficits, and (2) can assist also in the prevention of inflation by offsetting with public budget surpluses the effects of any private spending excesses.

With the means at hand, Congress was able to provide, by passing the Employment Act of 1946 , for the underwriting of national prosperity insurance. And though this was not Congress's primary intent, it is nevertheless true that the sound economic conditions thus guaranteed have provided the economic environment most conducive to maintaining the sound banking conditions which themselves best preserve the public's confidence in banks and bank money.

\section{G. Summary}

As of 1967 , the nation is in a position in which the maintenance of public confidence in its circulating medium of exchange is readily accomplished. The means at our disposal are listed here in the order of their relative importance, which happens also to be the reverse order of their historical development:

(I) prosperity insurance, providing that set of environmental circumstances in which it is most difficult for any bank to fail;

(2) a central bank equipped with both means and mandate continuously to adjust the banking system's liquidity position to conform to seasonal, cyclical, and secular changes in the total liquidity needs of the economy;

(3) deposit insurance, which serves as the ultimate guarantor of the banking system's solvency; and

(4) traditional banking regulation, predating all the others in point of time.

The last item has an American history going back for more than a century. In contrast, modern central banking and deposit insurance are but thirty years old; and prosperity insurance is but twenty years old.

A cultural lag clearly exists. Until only about a quarter-century ago, banking regulation supplied all the public influence for maintaining sound banking conditions that the state of economic and monetary knowledge permitted. Naturally, when it last failed in the hour of crisis, our first thought was to rebuild it much more massively, which we did, and then to reapply it much more rigorously, which we have been doing ever since. But now suddenly (and in the long view of history a quartercentury is sudden), $99^{44} 1100$ per cent of all the public influence needed to maintain sound banking conditions successfully and continuously can be and is being supplied from other sources. The residual $56 / 100$ of one per cent supplied by banking regulation is totally inadequate to justify the exceedingly complex system of constraints on individual bank operations built up in the mistaken belief that traditional banking regulation had a substantial role left to play in the maintenance of sound banking conditions. This is all the more significant since its current modus operandipreventing excessive banking competition-is most difficult to reconcile with its newer function of preserving banking competition. 
These facts are just beginning to be recognized, and their full acceptance may yet lie some years in the future. That circumstance in no sense diminishes their current validity, however. The commercial banking business, always unique in its moneycreating ability, is unique today for another reason as well: It is heavily but needlessly overregulated; the traditional reason for its public regulation has lost its meaning.

\section{II}

\section{Streamitining Traditional Banking Regulation}

Traditional banking regulation is no longer necessary to maintain public confidence in the banking system as a source of money supply. Sound individual banking conditions need no longer be sought through preventing excessive banking competition. What, then, should be done? The answer is obvious. We should rid ourselves of the excess of regulation which now serves the purpose only of stifling banking competition. Perhaps by that process, competitive conditions in banking may change to such an extent that regulation's newer purpose-preserving banking competition-may no longer need serving at all.

Traditional banking regulation consists, as we know, of (x) control of new bank chartering, (2) control of existing-bank de novo branching, (3) limitations on banks' ability to compete for earning assets, and (4) curtailment of bank's ability to compete for funds. Let us consider, in turn, the removal of each of these constraints.

\section{A. Bank Chartering}

To start a bank today, a charter must be obtained, and these are documents very difficult to come by. Under the dual system of chartering, which has accidently developed in the United States, the Comptroller of the Currency issues charters for national banks, and bank charters are granted in addition by bank regulatory authorities in each of the fifty states. The fifty-one bank chartering authorities operate with varying regulations and use different tests and procedures to determine whether a charter should be granted. None of the states has a procedural framework more elaborate than that employed by the Comptroller, however, so let us use his as illustrative.

Before a charter is issued for a new national bank, the Comptroller conducts an exhaustive investigation into the background and financial position of the organizers of the proposed bank, the present banking facilities available to its potential customers, and the probable need for and acceptance of a new banking institution in the area to be served. An examiner from the Comptroller's staff investigates the locale of the proposed bank and draws conclusions about each of the following factors: "the potential of management, earnings, and deposit forecasts, public need, capital adequacy, location and the general competitive climate in which the new bank would 
exist."14 All these formalities can be dispensed with except investigation into the background and financial position of the new bank's organizers, analysis of the potential of its management, and the adequacy of its capital. The continuing need for the first two of these seems too obvious to require specific comment. A slight digression on bank capital adequacy may now be in order, however.

\section{The Adequacy of Banking Capital}

Because of the high ratios of risky assets (loans) to total assets and the low ratios of capital to total liabilities and capital which are characteristic of American commercial banking, bank regulators have always been extremely concerned with the adequacy of a bank's capital to protect its depositors from losses arising out of shrinkages in asset values. Elaborate measures of capital adequacy have been devised, and banks failing to meet the tests of these measures are given a Hobson's choice: more capital or fewer risk assets.

Whether these capital adequacy measures ever had any real meaning, the facts today are these: Economic conditions are such that few banks ever fail; and for the few that do, deposit insurance, not individual bank capital, usually protects depositors from loss. Practically the only signifiance of capital adequacy at present, then, is as a limit on the FDIC's risk exposure.

Currently, insured commercial banks pay the FDIC a flat fee based on total deposits for insurance coverage. In the context of a system such as is being proposed, of practically free entry into the banking business, banks with low capital and very risky loan portfolios would have a chance to seek equity gains without having to bear commensurate risks of equity losses. Any gains they make are theirs to keep; but if they fail, the FDIC bears their losses.

To prevent this kind of thing from occurring, however, all that is necessary is to give the FDIC some power to control the risk exposure of its reserves. The simplest and most elegant method for handling this problem for a free-enterprise banking system in a free-enterprise economy has already been suggested: variable deposit insurance premium fees. That is, make the amount of a bank's assessment for deposit insurance a function of the ratio of the amount of its capital to the degree of risk in its loan portfolio. ${ }^{15}$ Coupled with our earlier suggestion that all banks, and ergo all new banks, should have all their deposits completely insured, this would seem to be all that is required. It has the additional advantage of making the basis for decisions on capital structure, cost of capital, and capital budgeting the same in banking as it is in other businesses.

\footnotetext{
${ }^{16}$ Hearings Before the House Comm. on Banking and Currency on Confict of Federal and State Banking Laws, 88th Cong., Ist Sess. 304 (I963) (statement of James J. Saxon, Comptroller of the Currency).

${ }^{15}$ See Jacobs, The Framework of Commercial Bank Regulation: An Appraisal, I Nat'L Banking Rev. 343,346 (I964).
} 


\section{Summary of Comments on Chartering}

The problems which control of entry into the banking business was designed to deal with are today being met by other means, including deposit insurance. Bank entry control can therefore largely be dispensed with. The only real constraint on entry that it seems necessary any longer to impose is not actually a constraint on entry per se but rather a constraint on continuing banking operations. It is intended to dull the incentive which the umbrella of deposit insurance extends over the taking of unreasonable banking risks. It can be readily provided by an appropriately designed system of variable deposit insurance premium fees. The application of such a system to all banks would serve, with respect to the entry of new banks into the business, as a modern substitute for outmoded minimum capital requirements and investigation into "community need" and "competitive climate"; and except for the continuance of minimal "character and competence" investigatory formalities, agreement to comply with it should constitute the only condition precedent to the granting of new bank charters.

\section{B. De Novo Branching}

From the earliest times, American states have imposed two sets of limits on statechartered banks. They may not branch across state lines, for example; that is, no state will permit a bank chartered in another state to operate within its borders. The traditional American (and especially rural American) fear of "foreign" money power, and the desire to keep local banking resources in local hands, are the probable explanations for this prohibition. They probably are also as good explanations as may be had for the second set of limits, which in two-thirds of the states either prohibits branch banking entirely or limits it to something less than a statewide basis. More precisely, only sixteen states permit branch banking on a statewide basis; twenty states permit it within limited areas; eleven prohibit it completely; and three have no legislation on the subject.

None of this might be especially significant had not Congress, in the Banking Act of 1933, as part of the effort to prevent in the future banking's alleged competitive excesses of the past, limited the branching powers of national banks to conform to those possessed by state banks in the states where the national banks existed and operated. ${ }^{16}$ Thus, state regulation sets the branching limits to which national banks are subject. And, as may be inferred from what has been said above, state regulation of branching tends to be quite restrictive.

To liberalize restrictions on de novo branching, Congress needs to undo what it did in 1933 with respect to national banks and then either to permit them un-

\footnotetext{
${ }^{10}$ I2 U.S.C. $\$ 36(\mathrm{c})(1964)$. That the statute did indeed have this effect was recently affirmed by the Supreme Court in First Nat'l Bank v. Walker Bank \& Trust Co., 385 U.S. 252 (r966). The Comptroller had attempted to give national banks somewhat broader branching powers.
} 
limited branching powers or to establish some new set of limits. Which should it be? As a starter, Congress might permit national banks to branch de novo on a statewide basis, subject only to the constraint developed with respect to bank chartering, that the deposit insurance fees of a bank-unit or branching-should be a function of the ratio of the amount of its capital to the degree of risk in its loan portfolio. Minimum capital requirements for branches might then be dispensed with, and the questions of public need and competitive climate could also be ruled out of account.

\section{Economies of Banking Scale.}

Economies of scale are known to exist in banking. Their realization begins as banks of very small size grow larger, and continues with further increases in bank size up to some unknown point. Let us set this point arbitrarily at $\$$ I billion in deposits for purposes of discussion. Even before such large bank sizes are reached, however, the realization of further scale economies as bank size further increases may diminish markedly. Thus there may be much less difference in banking efficiency between a $\$ \mathrm{I}$ billion bank and a $\$ 500$ million one than between a $\$ 500$ million bank and a \$roo million one.

The realization of scale economies should certainly be encouraged as a means to better customer service rendered by banks. Freeing de novo branching is one way of doing this, because it will lead to banks of larger average size. The question then remaining is this: What bank size leads to the realization of all reasonably possible economies of scale? Alternatively, beyond what size will further increases in size lead to diseconomies of scale in banking?

\section{Statewide Branch Banking}

No one really knows the answers to the questions posed above. Much current research is being devoted to seeking the answers because the answers are very important to a precise solution to the problem of whether and to what exent to change bank branching restrictions. What can be said with some certainty is that permitting de novo branching on a statewide basis will not exhaust economies of banking scale. Nor will it diminish the number of existing banks while leading to banks of larger average size. Though it pushes to the frontiers of existing knowledge about the economies of banking scale, then, it is really a very modest proposal. It does not permit nationwide branch banking, although that may someday seem desirable; and it does not carry the possible "concentration" effect of permitting statewide branching through merger. ${ }^{17}$ Achieving it may do some violence to the dual system, however. That is also true of freeing bank chartering, discussed above, and freeing bank competition for earning assets, discussed below. After considering the competition

\footnotetext{
${ }^{17}$ Branching through merger, and the use of holding companies as branch banking substitutes, are considered below in connection with preserving banking competition.
} 
for earning assets, therefore, the relationship of all three to the dual banking system will be regarded jointly.

\section{Competition for Earning Assets}

Banks are subject to a bewildering variety of specific limitations on the earning assets they may acquire, many stemming from the days when the productive credit theory of bank lending was in flower. None of them is any longer necessary so far as debt-type assets are concerned. Equity-type assets may be another matter. However, commercial banks must compete for funds (time and savings deposits) with nonbank financial institutions, some of which are permitted to invest in equities to some extent. The Commission on Money and Credit took cognizance of this fact when it suggested that, while bank investments in equities should continue to be restricted, commercial banks, in the investment of their savings and time deposits, should enjoy the least burdensome restriction on equity-type investments that is available to their nonbank competitors for funds. ${ }^{18}$

Banks are subject also to two general limitations on the earning assets they may acquire-capital adequacy constraints and legal reserve requirements. Capital adequacy constraints have already been dealt with, in connection with liberalizing the chartering of banks. Our discussion of freeing competition for earning assets can therefore be closed with a few words on legal reserve requirements.

They are the original instrument of banking regulation, first (and still) imposed by states on the banks they chartered in an effort to impose a minimum level of liquidity for deposit convertibility purposes. Instead, they turned out to have the effect of locking up liquidity, and should all have been repealed long ago. They were retained and elaborated, however, until the possibility of their use for monetary policy purposes was at last perceived. This use requires that they be made variable, as Federal Reserve reserve requirements have been since 1935, so that they may be raised to reduce excess liquidity in the banking system and lowered to reduce it. Stateimposed legal reserve requirements, applicable to state-chartered non-Federal Reserve member banks, are still not generally variable; but they should be.

That is, legal reserve requirements today are not an instrument of banking regulation but of monetary policy; and as a monetary policy instrument, they should be applied uniformly to all banks. What is needed, then, is to make nonmember banks subject to the Federal Reserve System's legal reserve requirements. This may be done in either of two ways: ( $\mathrm{I}$ ) require all commercial banks to be Federal Reserve member banks; or (2) more simply, if the previous suggestion that all commercial banks be required to be FDIC-insured banks is acted upon, require all insured banks, whether Federal Reserve member banks or not, to observe Federal Reserve legal reserve requirements. This second solution is the one we would propose.

\footnotetext{
${ }^{18}$ Commission on Money and Credit, Money and Credit: Their Influence on Jobs, Prices, and Growri I63-64 (Report of the Comm'n on Money and Credit, I96r).
} 


\section{Regulatory Streamlining and the Dual Banking System}

Thus far we have suggested:

(r) extending federal deposit insurance coverage to cover all deposits in all banks;

(2) substituting variable deposit insurance assessments (with the extent of variability being a function of the ratio of a bank's capital to the degree of risk in its loan portfolio) for present chartering and de novo branching restrictions;

(3) permitting de novo branching to occur freely on at least a statewide basis;

(4) eliminating present restrictions on the debt-type earning assets banks may acquire and liberalizing the restrictions on bank acquisition of equity-type earning assets; and

(5) making all (insured) banks subject to Federal Reserve System reserve requirements.

Each of these suggestions, if adopted, would have the effect of "undermining" the dual banking system. The first would force some 500 presently uninsured statechartered banks to become insured. The last would make state-imposed legal reserve requirements officially meaningless (as they already are, unofficially). The second, third, and fourth, applied by Congress initially only to national banks, ${ }^{10}$ would have the effect of making national banking charters more attractive, inducing presently state-chartered banks to become national banks, and forcing states either to conform to federal practice with respect to chartering, de novo branching, and bank asset acquisition, or to go out of the bank-chartering business.

They will conform, and stay in it, although it would possibly be better if they did not conform and went out. In any event, the fact that doing something undermines the dual banking system is no reason at all for not going ahead and doing it. The dual banking system was never meant to be. Preserving it at the cost of bank regulatory progress is nonsensical.

\section{E. Competition for Funds}

In the Banking Acts of 1933 and 1935, Congress ( 1 ) prohibited the payment of interest on demand deposits by all Federal Reserve member and FDIC-insured nonmember banks, ${ }^{20}$ and (2) limited the payment of interest on time (including savings) deposits to maximum rates specified by the Federal Reserve System for member banks and by the FDIC for insured nonmember banks. ${ }^{21}$

\footnotetext{
${ }^{10}$ Variable deposit insurance assessments would be applied to all insured banks; they would be substituted for present chartering and de novo branching restrictions only for national banks, however.

${ }^{20}$ I2 U.S.C. $\$ 371$ 1a (1964); 12 U.S.C.A. $\$$ I828(g) (Supp. I966).

${ }^{21}$ I2 U.S.C.A. $\$ 37 \mathrm{Ib}$ (Supp. I966); 12 U.S.C.A. $\$ 1828$ (g) (Supp. I966).
} 


\section{Prohibition of Interest Payments on Demand Deposits}

The prohibition of interest payments on demand deposits makes it impossible for banks to compete with each other for demand balances on a price basis. They are forced to compete instead on a nonprice or "quality and quantity of services rendered" basis. But, to the extent that they are rendered free of any stated charge, such services may be viewed as implicit interest payments on demand balances, paid by the banks to their customers for the use of customers' funds, and made necessary by the fact that explicit interest payments are no longer legally permitted.

The payment of implicit interest on demand balances, through the rendering of free services to depositing customers, is so ubiquitous in present-day American banking practice that once again permitting banks to pay explicit interest on demand deposits would merely widen an already existing avenue of interbank competition for funds. A price dimension (explicit interest payments) would be added to the already existing "quality and quantity of services rendered" dimension (implicit interest payments) of this competition. The competition would thereby be improved and made more effective, since bankers and bank customers would have a wider range of alternatives to offer and demand-interest payments, services rendered, or some combination of the two, instead of only services rendered, as at present.

\section{Limitation of Interest Payments on Time Deposits}

Though originally imposed to prevent excessive banking competition, the actual result over time of limiting the ability of commercial banks to pay interest in order to attract time (including savings) deposits has been to subsidize and promote the growth of nonbank financial institutions (savings and loan associations, mutual savings banks, and credit unions) which compete with banks for the economy's liquid funds but are more specialized than banks in their use of these funds in lending. These specialized institutions developed when banks were themselves less generalized in their lending (because of the influence of the productive credit doctrine) than they now are, or than they have been for some time. The specialized institutions then served a useful social and economic purpose. As banks have steadily expanded the scope of their lending, however, the social and economic usefulness of specialized lending institutions has declined commensurately.

The limitation of interest payments by banks on time and savings deposits is not necessary to prevent excessive banking competition. It is undesirable for yet another reason-it distorts the free market allocation of funds in order to protect the specialized financial institutions. The long-range public welfare would be better served if this did not occur. Only through exposure to market forces can the nonbank institutions be weaned away from a degree of specialization in lending which the economy no longer requires and directed toward a degree of lending generalization approaching that of banks. Such a change is highly desirable as a 
means of decreasing the existing degree of compartmentalization in the customer loan segment of the nation's money and capital markets and thus of making flows of funds more responsive to shifts in the structure of the economy's total loan demand.

The recent action taken by bank regulatory authorities in lowering the maximum rate of interest banks may pay on time balances under \$roo,00o from five and a half to five per cent is triply regrettable. ${ }^{22}$ Its purposes were two: (I) to protect specialized lending institutions in their competition for funds with banks by (2) masking the qualitative impact of the restrictive application of quantitative monetary policy. But it was accomplished by taxing small savers, in an opportunity cost sense, to provide the needed subsidy to the specialized lenders. This sort of thing should simply not be permitted to occur. In the absence of the present power to regulate bank interest payments on time deposits, it could not, of course. This alone is sufficient reason for suggesting that the power be removed, even without reference to the fact that it is no longer needed to prevent excessive banking competition.

\section{F. Summary}

Traditional banking regulation is no longer necessary to maintain public confidence in the banking system as a source of money supply; sound individual banking conditions need therefore no longer be sought through the medium of preventing excessive banking competition; thus we should rid ourselves of the excess of regulation which now serves only to stifle banking competition. This excess includes controlling new bank chartering and existing-bank de novo branching, limiting banks' ability to compete for earning assets, and curtailing banks' ability to compete for funds.

Specifically, following (I) extension of federal deposit insurance coverage to all deposits in all commercial banks, (2) all limitations on new bank chartering and existing-bank de novo branching (except for minimal "character and competence" investigations) should be removed, coincident with (3) substituting variable deposit insurance assessments (with the extent of variability being a function of the ratio of a bank's capital to the degree of risk in its asset portfolio) for the present flat rate fee based on size of deposits alone. And (4) de novo branching should then be permitted to occur on at least a statewide basis.

Further, (5) all present restrictions on debt-type assets which commercial banks are permitted to hold should be removed and the restrictions on bank acquisition of equity-type earning assets should be liberalized; (6) all (insured) banks should be made subject to Federal Reserve reserve requirements; and (7) prohibition of the payment of interest on demand deposits, together with (8) limitations on the bank payment of interest on time and savings deposits, should both be entirely eliminated.

${ }^{22}$ E.g., 3 I Fed. Reg. 12676 (I966), amending I2 C.F.R. $\$ 217.6(b)$ (1966) (effective Sept. 26, I966); 3 Fed. Reg. 15793 (1966), amending I2 C.F.R. $\$ 329.6$ (b) (I966) (effective Jan. I, I967); sec note following 12 U.S.C.A. $\$ 461$ (Supp. 1966). 
Implementing the first, second, fourth, fifth and sixth of these suggestions, regardless of the essential merit of the suggestions themselves, is bound to run afoul of the objection that doing these things "would weaken (undermine) the dual banking system." To be completely explicit about the matter, that is precisely one of the effects that is being sought. The dual banking system is a historical accident; it was never meant to be, but its accidental creation and subsequent development into one of American banking's most sacred cows has constituted a drag on banking progress long enough. It is now time for false though ancient icons to give way to policies more in keeping with modern conditions.

\section{III}

\section{Preserving Banking Competition}

Traditional banking regulation aims at protecting the users of bank money and bank depositors. Its thrust is at banks as sources of money supply and pools of community liquidity. Its purpose is preserving public confidence in the circulating medium of exchange. Its method consists of attempting to preserve public confidence in banks, by maintaining sound individual bank operating conditions, via the route of preventing excessive banking competition. Its instruments include controls over bank entry (chartering) and market expansion (de novo branching), limitations on bank earning-asset acquisition, and constraints on bank competition for deposits.

In contrast, the newer form of banking regulation which has developed only during the last decade aims at protecting the users of bank credit. Its thrust is at banks as extenders of credit, or lenders. Its purpose is to prevent the monopolistic exploitation of borrowers. Its method consists of attempting to assure borrowers of a reasonable number of alternative sources of credit accommodation, via the route of preserving banking competition. Its instruments include constraints on market expansion through (branching by) merger, and controls over bank holding company formations and expansion.

We have already concluded that excessive banking competition no longer needs preventing; that traditional banking regulation is meaningless and unnecessary; and we have suggested a number of actions designed to streamline it into conformity with modern banking and economic conditions. Taking these actions, and thereby removing the weight of the dead hand of traditional banking regulation from the banking system, would work powerfully in the direction of improving the existing degree of banking competition, both along the extensive margin of bank entry and market expansion, and along the intensive margin of competition by existing banks and branches for funds and for deposits.

The questions to which this final section proposes to address itself are two: (x) Does existing banking competition really need preserving? And (2) after traditional banking regulation is streamlined and modernized, what of the future of banking regulation? 


\section{A. Does Existing Banking Competition Need Preserving?}

Congress answered this question affirmatively in 1956 , by passage of the Bank Holding Company Act, ${ }^{23}$ and in $\mathrm{rg} 60$, by passage of the Bank Merger Act. ${ }^{24}$ It reaffirmed its belief that existing banking competition needs preserving in 1966 , by strengthening both acts through amendment. ${ }^{25}$

The Board of Governors of the Federal Reserve System has jurisdiction over the formation and expansion of all bank holding companies controlling the operations of two or more banks. As amended in 1966, the Bank Holding Company Act stipulates that

(c) The Board shall not approve-

(I) any acquisition or merger or consolidation under this section which would result in a monopoly, or which would be in furtherance of any combination or conspiracy to monopolize or to attempt to monopolize the business of banking in any part of the United States, or

(2) any other proposed acquisition or merger or consolidation under this section whose effect in any section of the country may be substantially to lessen competition, or to tend to create a monopoly, or which in any other manner would be in restraint of trade, unless it finds that the anticompetitive effects of the proposed transaction are clearly outweighed in the public interest by the probable effect of the transaction in meeting the convenience and needs of the community to be served.

In every case, the Board shall take into consideration the financial and managerial resources and future prospects of the company or companies and the banks con$L$ serned, and the convenience and needs of the community to be served. ${ }^{2 B}$

The amended Bank Merger Act contains a similar provision addressed to the Board (if the continuing bank is to be a state-chartered member bank), to the Comptroller (if the continuing bank is to be a national bank), and to the FDIC (if the continuing bank is to be a state-chartered nonmember insured bank), since the three agencies share jurisdiction over bank mergers. Additionally, in each case before it, each agency is required to seek advisory opinions from the other two, and also from the Attorney General, as to the competitive effects of the merger in question.

As they now read, therefore, both the Bank Holding Company Act and the Bank Merger Act appear to be efforts to apply the traditional antitrust approach in the traditional way, to promote competition and to prevent monopoly in the commercial banking business. ${ }^{2 \pi}$

\footnotetext{
${ }^{23}$ Ch. 240, 7o Stat. I33.

${ }^{21}$ Act of May 13, 1960, Pub. L. No. 86-463, 74 Stat. I29.

${ }^{28}$ I2 U.S.C.A. $\$ \S 184 \mathrm{r}-49$ (Supp. I966); I2 U.S.C.A. \$ I828(c) (Supp. I966).

${ }^{26}$ I2 U.S.C.A. $\$ 1842$ (c) (Supp. I966).

${ }^{27}$ This reading was recently confirmed by the Supreme Court in United States v. First City Nat'l Bank of Houston, 87 S. Ct. 1088 ( 1967 ).
} 


\section{Bank Holding Companies}

Registered ${ }^{28}$ bank holding companies constitute a sort of shadow empire within the banking system consisting at the end of 1965 of fifty-three banking groups, involving 468 banks which collectively operate 1,486 additional banking offices (branches) and altogether hold deposits of \$28 billion, or over eight per cent of the nation's total. ${ }^{29}$ The basis for their public regulation in the interest of preserving banking competition is the assumption that they are substitutes for branching-they provide the only means of multiple office banking across state lines as well as the only means of achieving statewide multiple office banking in those states (two-thirds of all the states) which either prohibit branch banking or limit it to something less than a statewide basis-and that their operations therefore resemble those of branching banks. Thus, a given concentration of banking assets and deposits in a holding company group is assumed to have the monopolistic overtones of the same concentration occurring in a branching bank. In the light of our present knowledge of holding company operations, this is an untenable assumption.

Nobody really knows whether and to what extent bank holding company groups actually operate as if they were branching banks (in such terms as the mobilization and movement of funds throughout the system from areas of loan deficit to those of loan surplus, enforcement of common lending policies on all their offices, and so on). The weight of such limited and inadequate evidence as is available suggests that they do not actually operate this way, however. ${ }^{30}$ But if they do not, then regulating them in the interest of preserving competition is pointless, since they are truly shadows without anticompetitive substance, and their individual units (banks) are each individual competitive entities in their own right.

Only if holding company groups do operate as if they were branching banks, then, is their public regulation in the interest of preserving banking competition justifiable; and then only to the extent that they in fact so operate. Since nobody knows either whether or to what extent group banking resembles branch banking in its operations and competitive effects, there is at present no clear case to be made for the public regulation of bank holding companies. Only after further research has succeeded in demonstrating the true nature of holding company operations, and the true extent of their resemblance to branch banking operations, can a meaningful approach to the regulation of bank holding companies be undertaken. The results of such further research are therefore urgently needed, and the research itself should quickly be begun. Until it is begun and completed, and its results become available for inspection, however, we can only say that it is not at all clear that commercial banking

\footnotetext{
${ }^{28}$ With the Board of Governors of the Federal Reserve System, thus conforming to the provisions of the Bank Holding Company Act. I2 U.S.C. $\$$ I844(a) (I964).

2052 Fed. Reserve BULl. 1250 ( 1966 ).

${ }^{30}$ See, e.g., Gerald C. Fischer, Bank Holding Companies (ig6i).
} 
competition needs preserving through the medium of publicly regulating the formation and expansion of holding companies in the field of banking.

\section{Bank Mergers}

Compared with the banking systems of other countries, the total number of banks we have is very large. Our typical bank is small, however, and we have only a few really large banks. Yet the large banks we do have hold a substantial fraction of the country's total banking assets. For example, as Table I indicates, of the 13,468 insured commercial banks in the United States at the end of 1964 , over 7,170 had deposits of $\$ 5$ million or less. Taken together, these banks held but 6.3 per cent of the total deposits of all insured commercial banks, however. At the other extreme, the seventy-five banks with deposits of $\$ 500$ million or more collectively held $4 \mathrm{r} .6$ per cent of the total deposits; the 355 banks with deposits of $\$ 100$ million or more held 6r.5 per cent of the total deposits; and the 656 banks with deposits of $\$ 50$ million or more (which amount to less than five per cent of the total number of American commercial banks) held over two-thirds (68.5 per cent) of the nation's total bank deposits.

TABLE I

Percentage Distribution of Deposits of All Insured Commercial Banks, by Size Groups of Banks, November I8, I964

\begin{tabular}{|c|c|c|c|}
\hline Size Group (deposits in millions of dollars) & Number & $\begin{array}{l}\text { Percent of Total } \\
\text { Number }\end{array}$ & $\begin{array}{c}\text { Percent of 'Total } \\
\text { Deposits }\end{array}$ \\
\hline 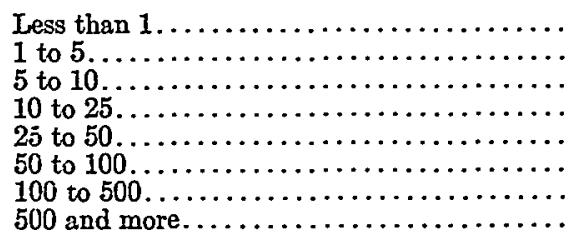 & $\begin{array}{r}693 \\
6,477 \\
2,908 \\
2,105 \\
629 \\
301 \\
280 \\
75\end{array}$ & $\begin{array}{l}5.1 \% \\
48.1 \\
21.6 \\
15.6 \\
4.7 \\
2.2 \\
2.1 \\
0.6\end{array}$ & $\begin{array}{l}0.2 \% \\
6.1 \\
6.9 \\
10.9 \\
7.4 \\
7.0 \\
19.9 \\
41.6\end{array}$ \\
\hline Toiai, all insered commercial bsnks....... & 13,468 & 100.0 & 100.0 \\
\hline
\end{tabular}

Source: 1964 FDIC ANN. REP. 112.

At the national level, this is the shape of the "banking concentration problem," which exists at regional, state, and local levels, as well. Bank merging-resulting from individual bank market expansion by branching through merger-is thought to accentuate this problem, and to pose a potential threat to banking competition, in two ways: (I) It reduces the number of banks, and (2) it increases the number of larger banks, and the concentration of deposits in those larger banks, while reducing the number of smaller banks.

Is merging's potential threat to banking competition actually a real one, in the sense that it leads in the direction of situations where potential borrowers may lack 
a reasonable number of alternative sources of credit accommodation? And even if this is so, is it still possible for "the anticompetitive effects of the proposed [merger to be] ... clearly outweighed in the public interest by the probable effect of the transaction in meeting the convenience and needs of the community to be served"? ${ }^{31}$

\section{Banking Competition}

There are 14,000 commercial banks in the United States, but they obviously do not all compete with each other. Rather, banking markets are "layered" into strata of national, regional, and local banking competition; and at the local level "segmented" into a large number of local banking markets each containing a relatively small number of competing banks.

There is really no question as to the adequacy of national and regional banking competition for the balances and borrowings of nationally and regionally operating business corporations and for the correspondent balances of local commercial banks. Even if we postulate (arbitrarily) that a bank needs to be quite large (say $\$ 500$ million in deposits or more) successfully to engage in national banking competition, there are still seventy-five banks this large (as Table I shows), and they do in fact compete very actively and aggressively with each other at the national level. If we further postulate (again arbitrarily) that a bank needs to have at least $\$ 100$ million or more in deposits to compete at the regional level, there are 355 banks this large (the seventy-five nationally competing banks with deposits of $\$ 500$ million or more plus 280 others with deposits of $\$ 100$ million and up to $\$ 500$ million); and there should be at least, say, roo of these (the seventy-five nationally competing banks plus at least twenty-five more in any particular region) available as alternative sources of credit accommodation to any regional borrower in any conceivable regional borrowing situation.

The adequacy of banking competition thus resolves into a question of the adequacy of local banking competition, or, more properly, the adequacy of local alternative sources of credit accommodation, since banks are not the only local sources of credit. Nonbank financial institutions-savings and loan associations, mutual savings banks, life insurance companies, government agencies, sales and consumer finance companies, and credit unions-effectively service many local borrowers in areas of credit accommodation in which banks are also active-residential mortgage financing, the extension of credit to farmers, and consumer instalment lending. Larger business borrowers have access to regional and national credit markets, as already noted. Even smaller business borrowers may have recourse to factors and commercial finance companies, for short-term credit, and to small business investment companies and state and local development corporations for term credit. It is nevertheless true that, as a class, small business borrowers must rely on local banks much more heavily than any other

\footnotetext{
${ }^{51}$ I2 U.S.C.A. $\$$ ×828(C) (5)(B) (Supp. 1966).
} 
class of borrowers; or, to put it another way, all other classes of borrowers already have a reasonable array (including local banks) of alternative sources of credit accommodation. The adequacy of banking competition may therefore be finally telescoped into the question of whether small business borrowers possess a reasonable number of local borrowing alternatives. This is certainly a much smaller question than the one we started out with; enough smaller, in fact, to make one wonder what the hue and cry surrounding the preservation of banking competition is really all about.

\section{Effects of Mergers on National and Regional Banking Competition}

It is really about no more than this, however, as a brief consideration of the effects of mergers on national and regional banking competition will readily show. At the national level there are seventy-five large competitors; a merger involving any two of them will leave seventy-four large competitors, one of which (the continuing bank in the merger) will be larger than it was before. The decrease in the number of competitors is negligible; the increase in size of one of the remaining competitors may carry with it economies of banking scale the realization of which will lead to some improvement in that bank's operating efficiency and, hence, competitive ability. If anything, then, the intensity of banking competition at the national level will be somewhat increased; it will certainly not be decreased.

At the regional level, there are more banking competitors in total-355, according to our arbitrary estimate-but not all of them will necessarily compete in any given regional borrowing situation. Nevertheless, our estimate of the minimum number that would compete-around a hundred, at least-is larger than the number of national competitors, which it includes. The competitive outcome of a merger at the regional level is bound to be in the same direction as that of one at the national level. If there is any difference, it is in favor of the proposition that regional banking competition will increase somewhat more in intensity as the result of a merger than will national banking competition. Again, it will certainly not be decreased. Only at the local level of competition, then, does the impact of a merger on banking competition seem to have any possible adverse significance.

\section{Effects of Mergers on Local Banking Competition}

The simplest concept of local banking market areas is the geographic one of "town" or community. Table 2 employs this simple concept roughly to distribute all local banking markets by number of banks and by proportion of total U.S. population contained. It seems reasonable to say that, with respect to five-or-more-bank towns, there is at present no problem of competitive adequacy, since each potential small business borrower has four or more sources of bank credit supply (in addition to whatever sources of nonbank credit supply may exist) alternative to any bank he approaches. And as for no-bank towns, there is nothing to say except that it would 
be better if they were at least one-bank towns. ${ }^{32}$ This leaves ninety-five per cent of the local banking markets, in which two-thirds of the total population resides, and in which the number of banks ranges from one to four. The number of bank alternatives to small business borrowers in these markets ranges from a minimum of none (in a one-bank town) to a maximum of three (in a four-bank town).

TABLE 2

Local Banking Market Areas By Number of Banks and Percent of Total Population

\begin{tabular}{|c|c|c|}
\hline Class of Market Area & $\begin{array}{c}\text { Percentage of } \\
\text { All Local } \\
\text { Banking Markets }\end{array}$ & $\begin{array}{l}\text { Percentage of Total } \\
\text { U. S. Population } \\
\text { Residing In }\end{array}$ \\
\hline \multirow[t]{2}{*}{ 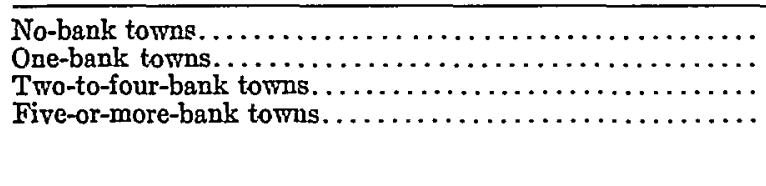 } & $\begin{array}{l}-\overline{50} \% \\
45 \\
5\end{array}$ & $\begin{array}{l}5 \% \\
20 \\
45 \\
30\end{array}$ \\
\hline & $100 \%$ & $100 \%$ \\
\hline
\end{tabular}

Source: Kreps, Characteristics of Local Banking Competition, in BANEING AND MONDTARY STUDIES 319, 330 (Carson ed. 1963).

In local banking markets as thus described, the competitive effects of two different kinds of merger possibilities must be differentiated: ( $I$ ) A bank outside the local market area branches by merger into the local market area, by acquiring an existing local bank. This is the only kind of merger possible in a one-bank town, and is much the more usual kind of merger to occur (or be proposed) in towns with more than one bank. (2) Two existing local banks merge into one. This sometimes happens in many (five or more) bank towns, but is a rarer occurrence in few (two to four) bank towns.

In the first and more usual kind of merger, the number of banks operating in the local market does not decrease. A branch of a larger bank is simply substituted for one of them. If the larger (merged) bank realizes economies of banking scale as a result of the merger, it becomes a more efficient bank, a more effective local competitor, and local banking competition is improved. And even leaving economies of banking scale out of account, it is hard to see how local banking competition can be worsened under such circumstances.

In the second and less usual kind of merger, the number of banks operating in the local market area does decrease. One larger bank is substituted for two of them. Substantial economies of banking scale must be realizable from such a merger to offset the loss of one of a few alternative sources of bank credit accommodation. Curiously, mergers of this sort (two local banks) usually do involve the possibility of

\footnotetext{
${ }^{32}$ Many of them will become at least one-bank towns if earlier suggestions are adopted that free de novo branching on at least a state-wide basis be permitted.
} 
substantial economies of banking scale, because they usually involve the smaller size ranges of banks. ${ }^{33}$ Often, in fact, the potential economies of scale are so large that their realization through the merger promises an increase in bank operating efficiency great enough more than to offset the loss of one of the few alternative sources of local bank credit accommodation for small business borrowers. Then the merger can be justified by a finding that "the anticompetitive effects of the proposed transaction are clearly outweighed in the public interest by the probable effect of the transaction in meeting the convenience and needs of the community to be served."

\section{Summary}

The public regulation of banking to preserve banking competition, undertaken only during the last decade, aims primarily at protecting the users of bank credit, by preventing their monopolistic exploitation by banks. Its thrust is therefore at banks as extenders of credit, or lenders. Its method consists of attempting to assure borrowers of a reasonable number of alternative sources of credit accommodation, by (I) controlling bank holding company formations and expansion and (2) constraining bank market expansion by branching through merger.

The regulation of bank holding companies is based on the assumption that they are substitutes for branching banks. In the present state of our knowledge of bank holding company operations, this is an untenable assumption. Until we know definitely that it is true, it is not at all clear that commercial banking competition needs preserving, or is preserved, through the medium of publicly regulating the formation and expansion of bank holding companies.

\footnotetext{
${ }^{33}$ It was earlier stated that economies of scale are known to exist in banking, that they begin as banks of very small size grow larger, and that they continue with further increases in bank size up to some unknown point. It was also said that the realization of scale economies in banking should be encouraged as a means of increasing banking efficiency, since this leads in the direction of better service rendered to their customers by banks. While little is known about the precise relationship between scale economies and changes in bank size, the evidence that is available suggests as a working hypothesis that the relationship includes at least four stages: (I) A first stage, as very small banks grow larger, in which realization of scale economies is very large and more than proportional to the increase in bank: size that accompanies them and makes them possible. This stage certainly covers the range of size increase up to \$50 million in deposits, and probably extends up to the neighborhood of \$roo million in deposits before it ends. (2) A second stage, covering the range of further increase in bank size from the end of the first stage (let us say, more or less arbitrarily, \$100 million in deposits) up to at least $\$ 500$ million in deposits and possibly on up to the neighborhood of $\$$ I billion in deposits, within which the possibilities of realizing scale economies are roughly proportional to further increases in bank size. (3) A third stage, ranging from the end of the second, wherever that may precisely be, on up to some unknown point of deposit size-\$3 billion, $\$ 5$ billion, $\$ 8$ billion, take your choice-within which the marginal realization of scale economies continues to be possible, but declines with further increases in size of bank, finally declining to a marginal realization rate of zero. Bcyond this, (4) a final stage of extremcly large bank sizes within which actual diseconomies of scale may begin to set in.

What this hypothesis suggests with respect to bank mergers is that (I) some scale economics are realizable from practically every bank merger; but (2) the smaller the size of the merging banks (and, consequently, of the merged bank in total), the larger are the possibilities for realizing scale economies through merger and achieving more efficient banking operations.
} 
The regulation of bank mergers proceeds from the beliefs that (I) there is a "banking concentration problem" and (2) bank mergers accentuate it. Because of the "layering" of banking competition into strata of national, regional, and local competition, the segmentation of local banking competition into a larger number of local banking markets each containing a relatively small number of competing banks, and the existence of economies of banking scale, however, neither belief can be conclusively demonstrated to be true.

At national and regional levels, mergers seem to improve banking competition more often than not; and they never seem to worsen it. At the local level, where the competitive problem posed by mergers resolves into one of providing small business borrowers with a reasonable number of borrowing alternatives, many if not most mergers do not reduce the number of locally competing banks; they merely increase the size of one of them. Scale economies realized from this increase in size may result in improved local banking competition. Even in the less usual case of two local banks merging, the substantial scale economies realizable from the merger (because the merging banks are usually relatively small) often more than offsets the loss of one of a few alternative credit accommodation sources, proving a basis for overriding competitive consequences and justifying the merger in terms of meeting community convenience and needs.

The relationship between mergers and banking competition therefore seems to be this: They usually improve competition; they almost never worsen it; and in the relatively few cases when they do, they generally serve a larger purpose-meeting community convenience and needs. Nothing in this relationship suggests that the public regulation of bank mergers is necessary to preserve existing banking competition.

\section{B. The Future Need for Banking Regulation}

Traditional banking regulation is outmoded; its streamlining to conform to modern banking and economic conditions will act powerfully to improve banking competition both along the extensive margin of bank entry and market expansion and along the intensive margin of competition by existing banks for funds and deposits.

Yet banking competition already seems to be in a reasonably satisfactory state in the sense that no clear-cut case can be made to the effect that there is a public need for preserving it through regulating merging and circumscribing grouping through the use of holding companies. This is all to the good. Streamlining traditional regulation will operate to make an adequate competitive situation even more adequate. None of the competitive improvement attributable to streamlining traditional regulation will be needed to cover an existing competitive deficit. It can all go to make merely adequate banking competition into dynamic and completely 
viable banking competition, returning the public-welfare benefits of vigorous competition into an area too long bereft of them.

We do not argue that at some point in time the case for publicly regulating merging and grouping, in the interests of preserving competition, will not be made. We only argue that at this point in time it cannot be made. Before it can be made, much additional research is needed in at least two strategic areas of the banking system's operations: the true role played by bank holding companies and the correct relationship between the realization of economies of banking scale and changes in banking size. We would stress again the need for such research to be undertaken, on a broad scale and immediately. In the meantime, in addition to the streamlining of traditional regulation that has been recommended, we would counsel only "standby" use of the present regulatory mechanism for controlling merging and grouping. That is, as an alternative to dispensing with it, possibly too soon, it should be used most sparingly and leniently, pending our gaining from research the information needed to make a proper final disposition of it.

Finally, we would urge that research undertaken not be confined solely to the two areas mentioned above. Gaining information in those two areas is essential to proper evaluation of the possible future need for public regulation aimed at preserving banking competition. But suppose that information reveals no such future need, as well it might. Our choice then will be to abandon banking regulation entirely or to turn it in other directions, where it may serve some legitimate public purposes.

Two such possible alternate public purposes may be mentioned, in the pursuit of either or both of which banking regulation may have much usefulness. These involve reshaping the banking system into (I) a more effective conduit of monetary policy influence, from the central bank to the economy, and/or (2) a more efficient accommodator of national economic growth. We believe that much thought and study should immediately be begun to be given to the possible reshaping of banking regulation to seek these goals. They are in the context of the national guarantee of prosperity insurance to which all public efforts are committed; bank regulatory success in achieving them would help make that guarantee even more effective. However the "banking competition controversy" is finally resolved, therefore, banking regulation should begin now to turn itself in these new directions. There is no question but that there is where its most constructive future lies. 